
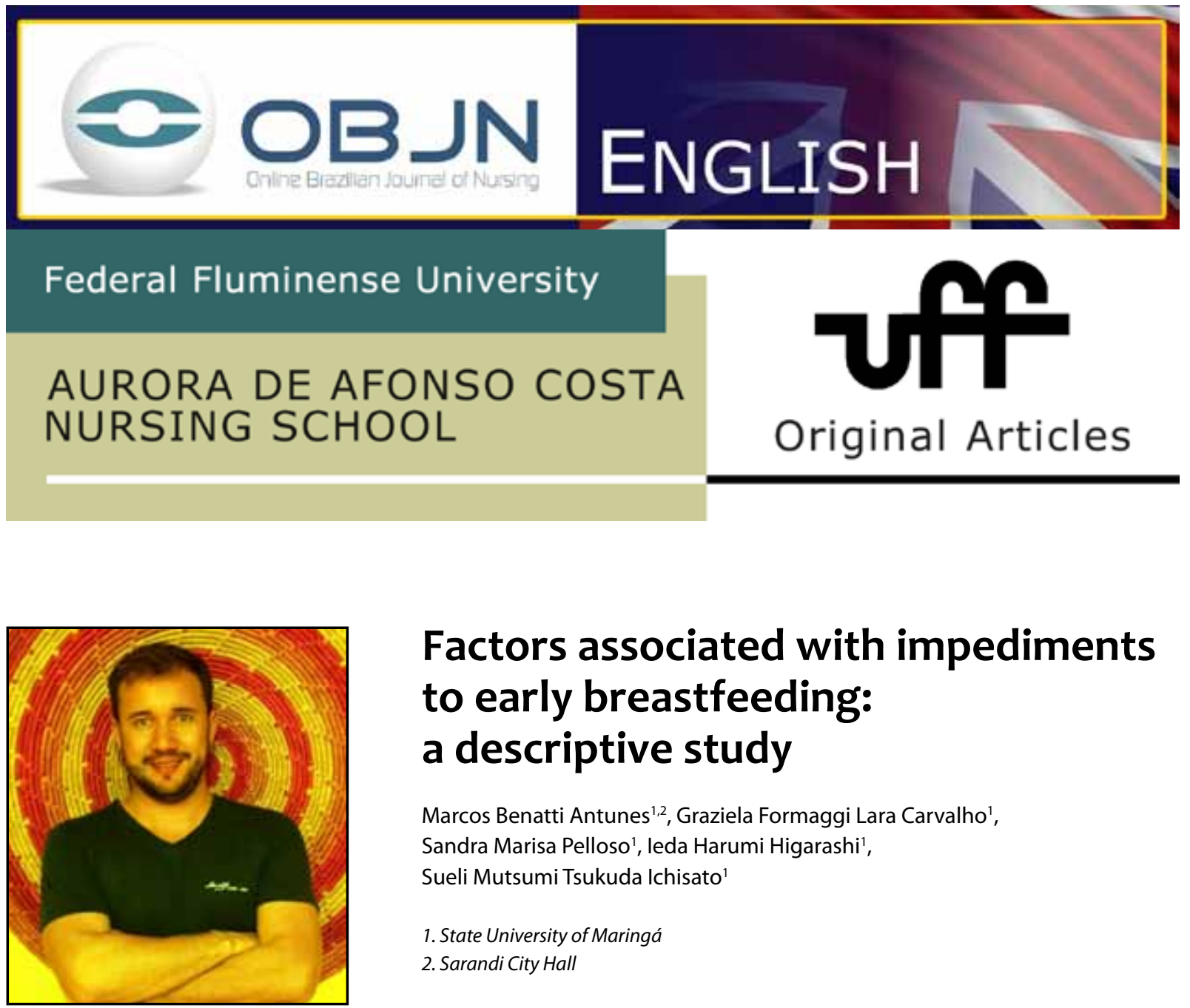

\title{
Factors associated with impediments to early breastfeeding: a descriptive study
}

\author{
Marcos Benatti Antunes ${ }^{1,2}$, Graziela Formaggi Lara Carvalho', \\ Sandra Marisa Pelloso', leda Harumi Higarashi', \\ Sueli Mutsumi Tsukuda Ichisato' \\ 1. State University of Maringá \\ 2. Sarandi City Hall
}

\section{ABSTRACT}

Aim: To check whether the fourth of the "ten steps to successful breastfeeding" is performed in a hospital in the northwestern region of Paraná. Method: an exploratory, descriptive study with a quantitative approach, conducted with 40 pregnant women in labor from July to October 2013. We used a semi-structured questionnaire and non-participant observation. To analyze the data we applied the chi-square test with Yates correction. Results: we identified a high number of caesarean section-births (33). Regarding motherinfant contact in the first hour, 39 mothers had eye contact, 32 has physical contact and only two breastfed in the first hour. Discussion: Some factors that prevented early breastfeeding and hindered the fourth step were found. Conclusion: the impediments found were the prevalence of cesarean delivery, the referral of baby to the nursery after delivery and the separation of hospital procedures from the model proposed by the Baby Friendly Hospital Initiative.

Descriptors: Breast Feeding; Normal Childbirth; Cesarean Section; Nursing. 


\section{INTRODUCTION}

A study in the United States in 2009 revealed that $76.9 \%$ of children had not been breastfed. Of those on breastfeeding, $47.2 \%$ were breastfed up to six months of age. Only $25.5 \%$ received breast milk up to 12 months of age $\mathrm{e}^{(1)}$.

In Brazilian capital cities, a study showed that the prevalence of breastfeeding in children under six months was $41 \%{ }^{(2)}$.

The barriers that prevent this are multifactorial and include mainly socioeconomic status and education. Low-income women have lower breastfeeding rates, a factor associated with early return to work after childbirth $^{(3)}$.

Breastfeeding brings numerous benefits to the mother-child relation in the first hour of life. This practice has been recommended by the World Health Organization (WHO) since 1990, and Brazil officially adopted it in 1992 through the Baby Friendly Hospital Initiative (BFHI), whose primary objective is to promote, protect and support breastfeeding, in order to achieve the reduction of child mortality, among other important aspects for the child and the mother ${ }^{(4-5)}$. In 2010, UNICEF released a list of 335 Brazilian institutions registered in the program as Baby-Friendly Hospitals $(\mathrm{BFH})^{(6)}$

To join the Initiative, it is necessary that the candidate hospital meets the ten steps to successful breastfeeding described by Unicef $^{(4)}$. All these are checked upon inclusion of the project in institution, as well as other required criteria, which go through three stages of evaluation: self-evaluation, pre-evaluation requested by the hospital and a visit of assessors from the Ministry of Health $(\mathrm{MOH})^{(5)}$.

Only one of the 18 accredited hospitals in Parana is located in the city of Maringa ${ }^{(6)}$.
The Regional University Hospital of Maringá (HUM) was accredited in 2003 after a project which was started in 1995 by a multidisciplinary team that aimed to reduce early weaning and infant mortality rate ${ }^{(7)}$.

The other hospital in the city seeking certification was the site responsible in 2011 for 2,960 live births (LB), or in other words, $44.04 \%$ (6721 LB) of births in the entire city ${ }^{(8)}$. Since 2002, this institution has been seeking to meet the ten steps in order to obtain the title of BFH. In 2009 it underwent a course of management, promoting, protecting and supporting breastfeeding for employees of the child care department by the Breastfeeding Committee of Maringa (COAMAR) in order to provide resources for a committed and humanized practice, and also to accredit the institution in the $\mathrm{MoH}^{(9)}$.

Despite the efforts made, this philanthropic institution is finding organizational difficulties in the realization of the fourth step ("help the mother to initiate breastfeeding in the first half-hour after birth"). This way, even though it includes a rooming-in service $(A C)$, the institutional procedures establish a flow in which the newborn (NB) undergoes immediate medical care and a bath before being taken to the site. Thus, the infant is not immediately referred with its mother to the rooming-in ward after labor, disregarding the recommendation of Ordinance no. 1016 of August $26^{\text {th }}$ of 1993 , which still calls for binomial contact in the first hour after birth ${ }^{(10)}$.

According to the $\mathrm{WHO}$, scientific evidence shows that putting the child in early contact with the mother's areola during the first hour after birth positively influences the mother-infant relationship. Infants cry less during skin-to-skin contact with the mother, which increases the prevalence of breastfeeding and decreases infant mortality rate ${ }^{(11)}$. 
In this sense, an ecological study held in 67 countries showed a relatively weak and negative but statistically significant correlation between breastfeeding percentage in the first hour of life and neonatal mortality rates, showing the protective effect of breastfeeding in the first hour of life ${ }^{(12)}$.

It is worth noting that the $\mathrm{MoH}$ stresses that the fourth step for the BFHI should be interpreted as putting the infants in direct contact with the mother immediately after delivery during the first hour of their lives and encouraging mothers to recognize when their babies are ready to be fed ${ }^{(4)}$. Thus, the identification of factors that influence helping the mother in breastfeeding is very important and can support the implementation of new strategies for the realization of the fourth step in hospitals ${ }^{(13)}$.

In this context, the knowledge attributed to the fourth step by health professionals is an important factor. In a study conducted in Recife with 80 professionals working in a delivery clinic, $42.4 \%$ did not know or did not remember what this step was ${ }^{(14)}$.

Thus, the objectives of this study were to assess the factors associated with non-implementation of early breastfeeding and to outline the care service practice regarding the completion of the fourth step to successful breastfeeding in a hospital in the northwest of Paraná.

\section{METHOD}

An exploratory, descriptive study with a quantitative approach, conducted with mothers attending a charity hospital in northwestern Paraná.

The study enrolled women who met the following inclusion criteria: pregnant women hospitalized by SUS, of 18 years of age or less, with gestational age of 38 weeks, pregnancies classified as low risk and with no complications during delivery. The sample included 40 pregnant women who received medical care in the period from July to October 2013.

Data were collected through semi-structured questionnaires with 21 questions including the identification of the mother, obstetric and neonatal data, track record of the labor process, birth, and initiation of breastfeeding. The researchers followed the process of parturition and birth until the moment of the mother-baby encounter in rooming-in using a Western ${ }^{\circledast} \mathrm{CR} 53$ digital stopwatch to record the time intervals between the procedures performed.

The empirical material was organized into a database using a Microsoft Excel 2010 spreadsheet. Data were analyzed by chi-square association test with Yates correction for $2 \times 2$ tables. The significance level was $5 \%$.

The outcome was defined as the initiation of breastfeeding during the baby's first hour of life, and the analysis was performed evaluating the interval between the health care interventions and any recorded impediments related to early breastfeeding.

The study was developed in accordance with current ethical regulations (Res. $466 / 2012$-CNS), with prior approval of the research project by the Ethics Committee on Institutional Research, according to opinion No. 449,631.

\section{RESULTS}

Of the 40 mothers interviewed, $55 \%$ (22) were aged $21-29,60 \%$ (24) were white and $77.5 \%$ (31) were married. As for education and work, $47.5 \%$ (19) had completed high school, 
$35 \%$ (14) had no paid activity and $65 \%$ (26) had a formal employment.

Gestational age ranged from 38 to 41 weeks; $50 \%$ (20) of patients started labor at 38 weeks of gestation and $2.5 \%(1)$ in the $41^{\text {st }}$ week of pregnancy.

The percentage of cesarean-section births was $82.5 \%$ (33), and all the patients underwent spinal anesthesia and remained awake throughout labor, according to the reports. The percentage of vaginal delivery was $17.5 \%$ (7); $2.5 \%$ (1) received local anesthesia and $5 \%(2)$ underwent unilateral episiotomy. In $32.5 \%$ (13) of deliveries, the father was present.

Most infants ( $92.5 \%$ or 37 babies) were born with a weight of $2500 \mathrm{~g}$ or more; $97.5 \%$ (39) had Apgar score between eight and ten in the fifth minute of life; $2.5 \%$ (1) were born presenting an anomaly (myelomeningocele). Only $2.5 \%$ (1) presented complications; $5 \%$ (02) were referred to the rooming-in in the first hour of life and 95\% (38) were sent straight to the nursery, remaining in that unit for more than one hour (Table 1).

Table 1. Distribution of newborns according to birth and referral to the rooming-in service in the first hour of life. Maringa, 2013.

\begin{tabular}{lcc}
\hline \multicolumn{1}{c}{ Newborns } & $\mathbf{n ~ ( 4 0 )}$ & $\%$ \\
\hline Gestational age & & \\
\hline 38-I 39 weeks & 20 & 50 \\
39-I 40 weeks & 12 & 30 \\
40—I 41 weeks & 7 & 17,5 \\
41 weeks & 1 & 2,5 \\
\hline Birth weight & & \\
\hline$<2500$ & 3 & 7,5 \\
$\geq 2500$ & 37 & 92,5 \\
\hline Issues & & \\
\hline No & 39 & 97,5 \\
Yes & 1 & 2,5 \\
\hline Anomalies & & \\
\hline No & 39 & 97,5 \\
Yes & 1 & 2,5 \\
\hline
\end{tabular}

\begin{tabular}{lcc}
\hline \multicolumn{3}{l}{ Referred to rooming-in service at first hour of life } \\
\hline No & 38 & 95 \\
Yes & 2 & 5 \\
\hline Apgar at 5th minute & & \\
\hline 7 & 1 & 2,5 \\
8 & 1 & 2,5 \\
9 & 22 & 55 \\
10 & 16 & 40 \\
\hline
\end{tabular}

$n$-number os subjects \% - percentage

Source: Authors' research

Regarding the mother-infant contact in the first hour of life, it was found that in $97.5 \%$ of births (39) there was eye contact, which ranged from zero to six minutes, with an average duration of thirty seconds and a mode of 10 seconds; $80 \%$ (32) had physical contact (Table 2). Of the professionals who assisted in this contact, $75 \%$ (30) were pediatricians, and $20 \%$ (08) were nursing technicians. In one case, the pediatrician handed the baby to his father so that he could present him to the mother; in another case, there was no professional assistance.

Table 2. Types and time of mother-infant contact in the first hour of infant's life. Maringa, 2013.

\begin{tabular}{|c|c|c|c|c|c|c|}
\hline $\begin{array}{l}\text { Type } \\
\text { of } \\
\text { con- } \\
\text { tact }\end{array}$ & $\begin{array}{l}\text { "Time } \\
\text { (se- } \\
\text { con- } \\
\text { ds)" }\end{array}$ & $\begin{array}{l}\text { "Me- } \\
\text { dian } \\
\text { (se- } \\
\text { con- } \\
\text { ds)" }\end{array}$ & $\begin{array}{c}\text { "Mode } \\
\text { (se- } \\
\text { gun- } \\
\text { dos)" }\end{array}$ & $\begin{array}{l}\text { Mini- } \\
\text { mum }\end{array}$ & $\begin{array}{l}\text { Maxi- } \\
\text { mum }\end{array}$ & $\begin{array}{c}\text { Stan- } \\
\text { dard } \\
\text { de- } \\
\text { via- } \\
\text { tion }\end{array}$ \\
\hline visual & 69,5 & 30 & 10 & 0 & 360 & 82,43 \\
\hline $\begin{array}{l}\text { physi- } \\
\text { cal }\end{array}$ & 52 & 20 & 0 & 0 & 300 & 78,96 \\
\hline
\end{tabular}

Source: Authors' research

In relation to breastfeeding, only $5 \%$ of mothers (2) who underwent normal childbirth breastfed their children in the first hour of life, and $100 \%$ of them were assisted by nursing technicians.

The chi-square test with Yates correction was applied to verify the association 
between type of delivery and time of arrival of the baby into the rooming-in. The $p$-value found was 0.00096 at $5 \%$ significance (Table $3)$, demonstrating that there is an association between mode of delivery and time of arrival of the baby in rooming-in.

Table 3. Type of delivery time of referral of baby at rooming-in service. Maringa, 2013.

\begin{tabular}{lcccc}
\hline Type of & \multicolumn{2}{c}{ Time of referral $(\mathbf{h})$} & $\mathrm{p}$-value & \multirow{2}{*}{ Total } \\
\cline { 2 - 4 } delivery & $\mathbf{5 0 1 : 0 0}$ & $>01: 00$ & $\mathbf{0 , 0 0 0 9 6}$ & \\
\hline Cesarean & 1 & 32 & & 33 \\
Vaginal & 4 & 3 & & 7 \\
Total & 5 & 35 & & 40 \\
\hline Soun
\end{tabular}

Source: Authors' research

In association analysis between the department the infant was referred to after delivery and the time elapsed until the mother-child meeting (Table 4), we also applied the chi-square test with Yates correction. The $\mathrm{p}$-value was 0.00611 , in other words, at $5 \%$ level of significance we found that there is an association between the variables.

Table 4. Department the baby was sent and binomial meeting time after delivery. Maringa, 2013.

\begin{tabular}{lcccc}
\hline Depart- & \multicolumn{2}{l}{ Time of arrival (h) } & p-value & Total \\
\cline { 2 - 4 } ment & $\leq 01: 00$ & $>01: 00$ & 0,00611 & \\
\hline Nursery & 3 & 35 & & 38 \\
Roo- & 2 & 0 & & 2 \\
ming-in & & & & \\
service & & & & \\
Total & 5 & 35 & & 40 \\
\hline $\begin{array}{l}\text { Source: Authors' research } \\
\end{array}$
\end{tabular}

\section{DISCUSSION}

Regarding the small sample size, the study's limitations make it impossible to generalize the results or even confirm that the barriers encountered in the realization of the fourth step in this care in reality constitute the main impediment to the achievement of $100 \%$ of breastfeeding in the city of Maringa.

However, we observed some factors associated to impediments to early breastfeeding and also to the non-realization of the fourth step proposed by the WHO, causing the prevalence of this to remain below expectations.

The Ministry of Health recommends that all infants should be placed next to the mother to suckle during their first half hour of life whenever both are in good condition, in order to stimulate eye and skin-to-skin contact between the binomial(5).

We noted in this study that, although visual and physical contacts have been propitiated, breastfeeding during the baby's first hour in the hospital continues to be poor. This fact was also reported in a study in a BFH by Recife in 2010, which assessed the implementation of the fourth step and identified that promotion of breastfeeding was minimal, accounting for nearly $60 \%$ of failure. This showed that the majority of cases (35.6\%) had no reason to justify not carrying out the fourth step ${ }^{(14)}$.

This information may be associated with the profile of obstetric care in relation to the type of delivery prevalent in the medical service, as well as to organizational barriers and factors that influence breastfeeding practices. In this context, it was possible to see in this study that the procedures of this hospital differ from the routines established by the model proposed by the BFHI, with regard to the fourth step to successful breastfeeding.

The BFHI has provided significant and necessary improvement in the rates of both beginning and duration of breastfeeding, as well as cultural, structural, technological and staff management changes that happen in hospitals that are now recognized as $\mathrm{BFH}$. 
These changes help to strengthen aspects such as exclusive breastfeeding, reduction of child mortality, narrowing of mother and baby relationships, improving the knowledge of professionals about the issue and recognition by the mothers regarding hospital staff work $^{(15)}$.

Scientific evidence shows that in Africa, $16 \%$ of neonatal deaths could have been prevented if all infants were breastfed from their first day of life, and $22 \%$ if breastfeeding were started within the first hour of life ${ }^{(16)}$.

Thus, we can affirm that it is worthwhile to encourage the expansion of $\mathrm{BFHI}$, especially in developing countries, in order to reinforce the importance of the program in promoting, protecting and supporting breastfeeding, which strengthens the Brazilian Public Health System (SUS) and contributes to the reduction of child mortality ${ }^{(13)}$.

Regarding the barriers to breastfeeding, some authors identify women's education, professional support, type of delivery and lack of information as the greatest problems standing against breastfeeding ${ }^{(2,3)}$.

In this study, pregnant women who underwent vaginal delivery were more likely to initiate breastfeeding early because the baby came to the room in less time when compared to cases where the mother had a caesarean section. The rooming-in is an essential factor for the promotion of breastfeeding and to facilitate the adoption of the practices set out in the "ten steps". This fact is evidenced in a survey conducted in the city of Vitoria in 2009 with 169 mothers and their babies, which showed prevalence of breastfeeding in the first hour of $63 \%$ and presented statistical significance of this variable with vaginal delivery $(p=0.007)$ and Rooming-in $(p<0.001)^{(17)}$.

The cesarean delivery stood out in the study as a deterrent factor, which can possi- bly increase the time of separation between mother and baby, and hinder their meeting in rooming-in and the early initiation of breastfeeding ${ }^{(17,18)}$. So, it is up to the organizations wishing to accredit up or which already have the BFH title, to lead the local midwifery service to reduce caesarean section rates to levels between $10 \%$ and $15 \%$ of all deliveries or apply the Robson classification to define the rate of local institutions as recommended by WHO, taking into account the indications for this procedure, improving interventions and behaviors that promote breastfeeding in the babies' first hour of life, even when vaginal delivery is not indicated ${ }^{(19)}$.

The association analysis performed in this study between the sector to which the infant was referred after delivery and the time of mother-infant meeting after birth showed that when the newborn is sent to the nursery, it becomes impossible for the mother to provide breastfeeding in baby's first hour of life. Accordingly, having a rooming-in service is not enough for the fourth step to occur. It is necessary to reduce the time mother and child are kept apart after birth. Thus, it is essential that all staff assisting these patients are properly guided and encouraged to stimulate such care.

In addition, it became clear that, despite the existence of the rooming-in service, the vast majority of infants were referred to the nursery after birth, although there was no apparent risk to justify the need for them to remain under observation by the nursing team. Of babies born by vaginal delivery that were referred to the nursery, the average time of stay in the department was 2:15h, while for those born by cesarean section, the average stay was 3:08h. This was one of the main reasons for the absenteeism of the mother-baby binomial and the primary impediment to the realization of early breastfeeding. 
A review of the systematic assistance procedures becomes therefore a priority to ensure that programs such as the BFHI are translated into routines that enable the achievement of planned objectives. The nurses, as the protagonists of the care process "must stand by this issue, working with their team, because these professionals have great potential to make changes and implement new practices that are essential for mother and baby"(20).

\section{CONCLUSION}

This study enabled us to understand the importance of the first contact between the mother and infant, both with regard to the formation of the primordial link between these two beings and to represent the singular mark of the first breastfeed.

Regardless of the institution's interest in joining the $\mathrm{BFHI}$, the care practice with regard to the realization of the fourth step to successful breastfeeding encounters contextual and organizational obstacles, requiring the need for change and the reorganization of the care procedures regarding postpartum and newborn care immediately after birth. Allowing the baby to be sent on to the mother in rooming-in in no risks situations ensures the sharing of a so important time in the life of the binomial, which is essential to the formation of the bond and in potentiating the benefits of early breastfeeding.

The results showed that the high number of caesarean sections is also a limiting factor to the institution which desires to achieve the goals proposed by the program, in addition to increasing the time of separation between mother and child.

Therefore, the implementation of educational activities that address the importance of breastfeeding in the first hour of life is essential. We observe a lack of preparation by the nursing staff and other professionals regarding the proper management of the fourth step. It is necessary to sensitize and train them to change practices in such a way that they meet the requirements of $\mathrm{MoH}$ and WHO in order to achieve the accreditation as a BFH aiming to promote, protect and support breastfeeding and also to improve the quality of care given to postpartum women and newborns.

\section{REFERENCES}

1. Centers for Disease Control and Prevention (US). Breastfeeding Report Card (US) [internet]. Atlanta (GA): CDC; 2012 [cited 2014 jul 14]; Available from: http://www.cdc.gov/breastfeeding/pdf/2012BreastfeedingReportCard. pdf. English.

2. Ministério da Saúde (BR). Secretaria de Atenção à Saúde. Departamento de Ações Programáticas e Estratégicas. II Pesquisa de Prevalência de Aleitamento Materno nas Capitais Brasileiras e Distrito Federal. Brasília (DF): Ministério da Saúde; 2009.

3. The American College of Obstetricians and Gynecologists. Breastfeeding in Underserved Women: Increasing Initiation and Continuation of Breastfeeding. Committee on Health Care for Underserved Women [internet]. 2013 [cited 2014 jul 14]. Number 570. Available from: http://www.acog.org/Resources-And-Publications/Committee-Opinions/Committee-on-Health-Care-for-Underserved-Women/Breastfeeding-in-Underserved-Women-Increasing-Initiation-and-Continuation-of-Breastfeeding

4. Ministério da Saúde (BR). Iniciativa Hospital Amigo da Criança: revista, atualizada e ampliada para o cuidado integrado. Módulo I: Histórico e implementação [Internet]. Brasília: Editora do Ministério da Saúde; 2008 [cited 2014 oct 07]. (Série A. Normas e Manuais Téc- 
nicos). Available from: http://bvsms.saude.gov. br/bvs/publicacoes/iniciativa_hospital_amigo_crianca_modulo1.pdf

5. Ministério da Saúde (BR). Área Técnica de Saúde da Criança e Aleitamento Materno. Departamento de Ações Programáticas Estratégicas. Secretaria de Atenção à Saúde. Iniciativa Hospital Amigo da Criança. Brasília (DF): Ministério da Saúde; 2011 [cited 2014 jan 25] Available from: http://bvsms.saude.gov.br/bvs/publicacoes/iniciativa_hospital_amigo_crianca.pdf

6. Fundo das Nações Unidas para a Infância (UNICEF). Lista dos Hospitais Amigo da Criança (Online). [cited 2015 nov 08]. Available from: http://www.unicef.org/brazil/pt/activities_9998.htm

7. Hospital Universitário Regional de Maringá. História do hospital. Maringá (PR); 2013 [cited 2013 apr 19]. Available from: http://www.hum. uem.br/estrutura/amigo-das-criancas/

8. Hospital Santa Casa de Maringá. Desempenho Hospitalar. Revista Institucional da Santa Casa de Maringá. Humanização: vida, saúde e solidariedade [internet]. 2012 [cited 2012 nov 08] 2(1): 44-45. Available from: http://issuu. com/studio_eureka/docs/revista_humanizacao_santacasa_2012/1

9. Zanatta M. Comitê de aleitamento promove curso para Santa Casa. Jornal do Povo. (Online) [internet]. 2009 may 02 [cited 2013 may 18]. Available from:http://www.maringamais.com. $\mathrm{br} /$ ?pag=noticias_destaque\&id $=1552$

10. Ministério da Saúde (BR). Programa Nacional de Incentivo ao Aleitamento Materno. Grupo de Defesa da Saúde da Criança. Normas e rotinas para o incentivo ao aleitamento materno: Passo 1. Brasília(DF): Ministério da Saúde; 1993.

11. World Health Organization, UNICEF. Baby-friendly Hospital Initiative: Revised, updated, and expanded for integrated care. Geneva: World Health Organization; 2009.

12. Boccolini CS, Carvalho ML, Oliveira MIC, Pérez-Escamilla R. Breastfeeding during the first hour of life and neonatal mortality. Jornal de Pediatria (Online) [internet]. 2013 [cited 2014 oct 14]. 89(2): 131-136. Available from: https://www.icict.fiocruz.br/sites/www.
icict.fiocruz.br/files/A\%20amamentacao\%20 na\%20primeira\%20hora\%20de\%20vida\%20 e\%20mortalidade\%20neonatal.pdf

13. Bocollini CS, Carvalho M L, Oliveira MIC, Vasconcelos, AGG. Fatores associados à amamentação na primeira hora de vida. Rev. Saúde Pública (Online) [internet]. 2011 [cited 2014 jul 14]. 45(01): 69-78. Available from: http://www. scielo.br/pdf/rsp/v45n1/1717.pdf

14. Monte GCSB, Leal LP, Pontes CM. Avaliação do $4^{\circ}$ passo para promoção do aleitamento materno em hospital amigo da criança. Rev Rene (Online) [internet]. 2012 [cited 2015 nov 08]. 13(4): 861-70. Available from: http://www. revistarene.ufc.br/revista/index.php/revista/ article/view/1081/pdf

15. Vannuchi MTO, Monteiro CA, Réa MF. Implantação da iniciativa hospital amigo da criança em um hospital universitário. Cienc Cuid Saude (Online) [internet]. 2012 [cited 2014 oct 10]. 11(suplem.): 102-107. Available from: http:// www.periodicos.uem.br/ojs/index.php/CiencCuidSaude/article/view/17060/pdf

16. Edmond KM, Zandoh C, Quigley MA, Amenga-Etego S, Owusu-Agyei S, Kirkwood BR. Delayed breastfeeding initiation increases risk of neonatal mortality. Pediatrics [internet]. 2006 [cited 2014 oct 22]. 117: e380-386. Available from: http://pediatrics.aappublications.org/ content/pediatrics/117/3/e380.full.pdf

17. Boccolini CS, Boccolini PMM, Carvalho ML, Oliveira MIC. Padrões de aleitamento materno exclusivo e internação por diarréia entre 1999 e 2008 em capitais brasileiras. Ciênc. saúde coletiva (Online) [internet]. 2012 [cited 2015 nov 07]. 17(7): 1857-63. Available from: http:// www.scielo.br/pdf/csc/v17n7/25.pdf

18. Will TK, Arndt JG, Torres GG, Andrade JR, Pereira TSS, Molina MCB. Fatores de proteção para a amamentação na primeira hora de vida. Rev Bras Promoc Saude (Online) [internet]. 2013 [cited 2015 nov 09]. 26(2): 274-280. Available from: http://www.redalyc.org/articulo. oa? id=40828920016

19. Organização Mundial de Saúde (OMS). Declaração da OMS sobre taxas de cesáreas (Online). 2015 [Citado 08 Nov 2015]. Disponível em: http://apps.who.int/iris/bitstre- 
am/10665/161442/3/WHO_RHR_15.02_por. pdf?ua $=1 \& u a=1$

20. Strapasson MR, Fischer AC, Santos C, Bonilha ALL. Amamentação na primeira hora de vida em um hospital privado de Porto Alegre/RS relato de experiência. R. Enferm. UFSM (Online) [internet]. 2011 [cited 2014 jul 18]. 1(3): 489496. Available from: http://cascavel.ufsm.br/ revistas/ojs-2.2.2/index.php/reufsm/article/ view/2824/2412
All authors participated in the phases of this publication in one or more of the following steps, in According to the recommendations of the International Committee of Medical Journal Editors (ICMJE, 2013): (a) substantial involvement in the planning or preparation of the manuscript or in the collection, analysis or interpretation of data; (b) preparation of the manuscript or conducting critical revision of intellectual content; (c) approval of the versión submitted of this manuscript. All authors declare for the appropriate purposes that the responsibilities related to all aspects of the manuscript submitted to OBJN are yours. They ensure that issues related to the accuracy or integrity of any part of the article were properly investigated and resolved. Therefore, they exempt the OBJN of any participation whatsoever in any imbroglios concerning the content under consideration. All authors declare that they have no conflict of interest of financial or personal nature concerning this manuscript which may influence the writing and/or interpretation of the findings. This statement has been digitally signed by all authors as recommended by the ICMJE, whose model is available in http://www.objnursing.uff.br/normas/DUDE_eng_1306-2013.pdf

Received: $19 / 01 / 2015$

Revised: $18 / 11 / 2015$

Approved: 18/11/2015 